\title{
POLITIK HUKUM PIDANA \\ DALAM UPAYA PENGHAPUSAN KEKERASAN RUMAH TANGGA SEBAGAI WUJUD PENGAKUAN DAN PERLINDUNGAN HAM
}

\author{
Nadir \\ (D osen Fakultas H ukum U niversitas M adura Jl. Raya Panglegur km. 3,5 \\ Pamekasan)
}

\begin{abstract}
A bstract:
Violence in household such as physical, psychological, sexual and economical violence is a form of criminal action happens in household in which the doer and victim are from the same household. The way of penal policy through the government in solution of violence in household is formed in norm codification of positive law (positive wettelijk), by carrying out UU number 23 of 2004 about abolition of violence in a household. This regulation is a form of government attention to human rights (HAM), and gender, non discrimination and the protection of violence victims in a household.
\end{abstract}

\section{Key Words:}

KDRT, hukum pidana, HAM, dan patriarkhi.

\section{Pendahuluan}

Kekerasan terhadap fisik dan psikis yang terjadi antara sesama manusia tidak dapat dilepaskan dari asal-muasal manusia di muka bumi dan bagaimana manusia berinteraksi satu sama lain. Kekerasan antar sesama manusia itu merupakan mozaik sejarah peradaban manusia yang terjadi pada masa lalu, masa kini, dan masa yang akan datang.

Seiring dengan hal tersebut di atas sering kita menyaksikan terjadinya kekerasan dalam rumah tangga baik di media cetak, media elektronik, maupun di media lain baik kekerasan fisik, psikis, seksual, 
Nadi $r$

dan kekerasan ekonomi. Kekerasan yang terjadi di dalam rumah tangga pada dasarnya sering dilakukan oleh suami terhadap istri, oleh suami istri terhadap pembantu dan lain-lain.

Ditinjau dari segi tempat terjadinya, kekerasan fisik dan psikis terjadi dalam lingkungan rumah tangga atau di luar rumah tangga. Ditinjau dari segi pelakunya kekerasan fisik dan psikis dalam rumah tangga dapat dibedakan antara pelaku orang dewasa (suami, istri, pembantu rumah tangga) dan orang dewasa dengan anak-anak (orang tua terhadap anak dan sebaliknya). Sebaliknya di luar rumah tangga, kekerasan tersebut dapat dilakukan laki-laki maupun sesama perempuan. ${ }^{1}$

Penyebab utama kekerasan terhadap istri adalah ketidaksetaraan dan ketidakadilan gender yang menempatkan perempuan subordinat terhadap laki-laki, sehingga istri dianggap milik suami. 2 Pendapat ini didasarkan pada anggapan bahwa laki-laki bukan saja pencari nafkah keluarga. Oleh karena itu, laki-laki dianggap sah dan berhak memperlakukan istri sekehendak hati. Kondisi sosial budaya semacam itu terus-menerus bertahan pada masyarakat, sehingga walaupun seorang perempuan bekerja ataupun berpendidikan lebih tinggi, kedudukannya tetap subordinat yang berarti harus melayani suami dan keluarga serta berhak diperlakukan semaunya.

Menurut teori politik hukum, hadirnya Undang-Undang Nomor 23 Tahun 2004 merupakan salah satu bentuk kebijakan (policy) pemerintah sebagai legislasi nasional dalam rangka menghapus kekerasan dalam rumah tangga yang selama ini terjadi dan juga sebagai payung hukum bagi saksi sekaligus korban kekerasan dalam rumah tangga untuk melindungi dirinya di dalam proses peradilan pidana dalam persidangan. Hal ini didasarkan pada fakta bahwa walaupun kekerasan dalam rumah tangga merupakan bentuk tindak pidana, pengungkapan kekerasan dalam rumah tangga oleh sebagian masyarakat Indonesia dianggap suatu hal yang tabu untuk diungkap ke publik.

\footnotetext{
1 Herkutanto, Kekerasan terhadap Perempuan dan Sistem Hukum Pidana: Pendekatan dari Sudut Kedokteran (Bandung: Alumni, 2000), hlm. 263

2 Indriyati Suparno, et. al, Persepsi Pengetahuan Perempuan dan Gambaran Situasi Kekerasan terhadap Istri (Solo: Solidarity Kemanusiaan Perempuan, 2002), hlm. 3
} 


\section{Hak-hak Korban dan Penghapusan Kekerasan dalam Rumah Tangga}

Kekerasan dalam rumah tangga adalah setiap perbuatan terhadap seseorang terutama perempuan, yang berakibat timbulnya kesengsaraan atau penderitaan secara fisik, seksual, psikologis, dan/ atau penelantaran rumah tangga termasuk ancaman untuk melakukan perbuatan, pemaksaan, atau perampasan kemerdekaan secara melawan hukum dalam lingkup rumah tangga. ${ }^{3}$

Kekerasan dalam rumah tangga dalam pengertian luas menunjuk pada kekerasan yang mana pelaku dan korbannya berada dalam lingkup rumah tangga yang terdiri dari: suami, istri, anak, pembantu rumah tangga yang bekerja pada rumah tersebut. Dan yang sering menjadi korban kekerasan dalam rumah tangga adalah pada istri. ${ }^{4}$

Pasal 5 Undang-Undang Nomor 23 Tahun 2004 menyatakan bahwa setiap orang dilarang melakukan kekerasan dalam rumah tangga terhadap orang dalam lingkup rumah tangga dengan cara: pertama, kekerasan fisik; kedua, kekerasan psikis; ketiga, kekerasan seksual; keempat, penelantaran rumah tangga".

Selanjutnya pasal 10 Undang-Undang Nomor 23 Tahun 2004 menegaskan bahwa korban berhak mendapatkan:(1) Perlindungan dari pihak keluarga, kepolisian, kejaksaan, pengadilan, advokat, lembaga sosial, atau pihak lainnya baik sementara maupun berdasarkan penetapan perintah perlindungan dari pengadilan; (2) Pelayanan kesehatan sesuai dengan kebutuhan medis; (3) Penanganan secara khusus berkaitan dengan kerahasiaan korban; (4) Pendampingan oleh pekerja sosial dan bantuan hukum pada setiap tingkat proses pemeriksaan sesuai dengan ketentuan peraturan perundang-undangan; dan (5) Pelayanan bimbingan rohani.

Untuk mewujudkan semua hak korban kekerasan dalam rumah tangga sebagaimana disebutkan di atas, maka pemerintah dan pemerintah daerah sesuai dengan tugas dan fungsinya masingmasing dapat bekerja sama dengan masyarakat dan lembaga-lembaga

3 Pasal 1 butir 1 Undang-Undang No. 23 Tahun 2004

4 Farha Ciciek, Ikhtiar M engatasi Kekerasan Dalam Rumah Tangga (Jakarta: The Asian Foundation, 1999), hlm. 22 
Nadi $r$

penegak hukum terkait, dengan melakukan upaya: (1) Penyediaan ruang pelayanan khusus di kantor kepolisian; (2) Penyediaan aparat, tenaga kesehatan, pekerja sosial, dan pembimbing rohani; (3) Pembuatan dan pengembangan sistem dan mekanisme kerja sama program pelayanan yang melibatkan pihak yang mudah diakses oleh korban; dan (4) Memberikan perlindungan bagi pendamping, saksi, keluarga, dan teman korban

Menjamin hak-hak perempuan di bidang hukum dan kebijaksanaan serta jaminan kepada perempuan. Negara tidak saja wajib menjamin persamaan hak secara de jure (substansi hukumnya) tetapi juga dari segi de facto, yaitu dengan mendorong realisasi terwujudnya hak perempuan. Kewajiban negara meliputi mencegah diskriminasi terhadap perempuan, melarang diskriminasi perempuan, melakukan identifikasi adanya diskriminasi terhadap perempuan dan menjalankan langkah-langkah untuk mengatasinya, melaksanakan sanksi atas tindakan diskriminatif terhadap perempuan, memberikan dukungan pada penegakan hak-hak perempuan dan mendorong persamaan, kesetaraan dan keadilan melalui langkah proaktif, dan meningkatkan persamaan de facto perempuan dan laki-laki.

\section{Kekerasan dalam Rumah Tangga sebagai Pelanggaran HAM}

Menurut Erna Sofyan Syukrie5, di dunia Barat ataupun Timur, perkembangan peradaban manusia tumbuh dalam lingkup budaya dan ideologi patriarkhi. Di negara-negara Barat, Amerika Serikat, dan Eropa Barat, budaya tersebut terlebih dahulu terkikis sejalan dengan perkembangan teknologi dan demokrasi, yang mendudukkan persamaan dan keadilan sebagai nilai yang sentral. Di negara-negara dunia ketiga, termasuk Indonesia, budaya dan ideologi tersebut masih sangat kental dan mewarnai berbagai aspek kehidupan dan struktur masyarakat serta menciptakan ketimpanganketimpangan gender. Budaya dan ideologi bukan satu hal yang turun

5Erna Sofyan Syukrie, 2003, "Pemberdayaan Perempuan Dalam Pembangunan Berkelanjutan", makalah disampaikan dalam seminar loka karya pembangunan hukum nasional ke VIII diselenggarakan oleh Badan Pembinaan Hukum Nasional Departemen Hukum dan HAM RI Tanggal 14 sampai dengan 18 Juli 2003 di Hotel Kartika Plaza, Denpasar, Bali 
dari langit, melainkan dibentuk oleh manusia dan disosialisasikan dari satu generasi ke generasi berikutnya.

Nilai budaya adalah faktor mental yang menentukan perbuatan seseorang atau masyarakat. Dalam budaya kita, budaya patriarkhi masih sangat kental. Dalam kehidupan sosial, politik, ekonomi, dan terlebih lagi dalam budaya, keadaan ketimpangan, asimetris dan subordinatif terhadap perempuan tampak sangat jelas. Dalam kondisi yang seperti itu proses marjinalisasi terhadap perempuan terjadi pada gilirannya perempuan kehilangan otonomi atas dirinya. Eksploitasi serta kekerasan terjadi terhadap perempuan, baik di wilayah domestik maupun publik. Dalam situasi demikian, maka perbedaan, diskriminasi, dan ketidakadilan gender tumbuh dengan suburnya. Hal ini ironis karena secara formal, dalam UUD 1945, hak laki-laki dan perempuan tidak dibedakan (sama), namun dalam tataran empiris sangat berbeda.

Bagi masyarakat tradisional, patriarkhi dipandang sebagai hal yang tidak perlu dipermasalahkan, karena hal tersebut selalu dikaitkan dengan kodrat dan kekuasaaan yang tidak terbantahkan. Kepercayaan bahwa Tuhan telah menetapkan adanya perbedaan lakilaki dan perempuan, sehingga perbedaan dalam kehidupan manusia juga diatur berdasarkan perbedaan tersebut. Faktor agama juga telah digunakan untuk memperkuat kedudukan kaum laki-laki. Determinise biologis juga telah memperkuat pandangan tersebut. Artinya. karena secara biologis perempuan dan laki-laki berbeda maka fungsi-fungsi sosial ataupun kerja dengan masyarakat pun diciptakan berbeda.

Dalam pendidikan yang merupakan proses yang sangat penting bagi pertumbuhan nalar seseorang, juga masih sangat patriarkis. Satu keluarga biasanya akan lebih memberikan prioritas kepada anak laki-laki karena ia adalah penerus keluarga sedangkan anak perempuan akan pindah dan masuk ke dalam keluarga lain. Pendidikan dalam keluarga pun mensosialisasikan bahwa bapak adalah sentral, sehingga secara tidak disadari akan mengecilkan peran perempuan dalam keluarga. Anak perempuan jarang dilibatkan dalam pembicaraan kebijakan keluarga sehingga sosialisasi pada norma-norma yang semacam itu akan berdampak pada pembentukan kepribadian dan sikapnya yang cenderung tidak terbuka. 
Nadi $r$

Tindak pidana kekerasan dalam rumah tangga khususnya tindak kekerasan terhadap istri dalam keluarga umumnya terjadi karena banyak masyarakat masih meyakini dan didominasi budaya patriarkhi. Secara harfiah patriarkhi berarti sistem yang menempatkan ayah (laki-laki) sebagai penguasa keluarga. Istilah ini kemudian digunakan untuk menjelaskan pada suatu masyarakat tempat kaum laki-laki berkuasa atas kaum perempuan dan anak-anak hal ini dapat diartikan bahwa laki-laki adalah superior dan perempuan adalam inferior sehingga laki-laki dapat dibenarkan untuk menguasai dan mengontrol perempuan dan kedudukan perempuan tersebutr sub ordinat. Perwujudan patriarkhi sebagai sebuah sistem nilai budaya ini dipratikkan dalam berbagai institusi kehidupan masyarakat, baik dibidang ekonomi, politik maupun dalan institusi keluarga. Menurut Kate Millet dalam bukunya Sexual Politics, sebagaimana dikutip oleh Suparno, patriarkhi pada awalnya tumbuh dan berkembang secara mapan dalam kehidupan keluarga dimana pada dasarnya keluarga adalah bagian utama dari struktur kekuasaan masyarakat yang secara langsung maupun tidak langsung ikut melestarikan kekuasaan patriarkhi. ${ }^{6}$

Berpijak dari beberapa pendapat yang dikemukakan di atas, menurut penulis dalam beberapa konteks atau ranah tertentu kekerasan dalam rumah tangga dapat dikatakan pelanggaran $\mathrm{Hak}$ Asasi Manusia (HAM) dan termasuk kejahatan terhadap martabat kemanusiaan serta bentuk diskriminasi yang harus dihapus, sebagaimana dalam dijelaskan dalam Pasal 28 I ayat (2) UUD Negara Republik Indonesia Tahun 1945 bahwa "Setiap orang berhak bebas dari perlakuan yang bersifat diskriminatif atas dasar apa pun dan berhak mendapatkan perlindungan terhadap perlakuan yang bersifat diskriminatif ".

Meskipun dalam masyarakat tradisional yang memang dengan budayanya mereka menempatkan posisi perempuan di bawah laki-laki (tidak seimbang/subordinat), keadaan demikian tidak dikatakan pelanggaran HAM. Pada dasarnya dalam konteks sesama manusia, Allâh SWT telah menempatkan posisi perempuan sejajar dengan laki-laki, yang membedakan hanyalah ketaqwaannya. Dalam konteks rumah tangga laki-laki memang sebagai imam atau panutan keluarga sepanjang masih berada dan sesuai dengan syarî'at

6 Suparno, P ersepsi Pengetahuan, hIm.8 
Islam. Namun demikian, bukan berarti laki-laki sekehendaknya sendiri melakukan perempuan seperti budak. Jauh sebelum ada konferensi CED A W , Islâm telah lebih dahulu mendeklarasikan untuk mengatur dan mengangkat derajat perempuan, hanya tinggal impelementasinya di dalam kehidupan berbangsa dan bernegara ini.

\section{Politik Hukum Pidana (Penal Policy) dalam Penghapusan Kekerasan Rumah Tangga \\ Ada beberapa ahli hukum yang telah memberikan konsepsi} tentang politik hukum, namun penulis hanya mengutip pendapat Teuku Muhammad Radhie yang lebih pas dalam kajian ini, politik hukum dalam pandangan Radhie adalah sebagai suatu pernyataan kehendak penguasa Negara mengenai hukum yang berlaku di wilayahnya, dan mengenai arah perkembangan hukum yang dibangun. ${ }^{7}$

Mencermati kata "kehendak penguasa negara" dalam rumusan politik hukum di atas, maka dengan nyata bahwa undang-undang itu lahir dan diciptakan sesuai dengan keinginan penguasa negara mengenai kapan undang-undang itu dibuat dan kapan undangundangkan itu diberlakukan, setelah undang-undang itu diberlakukan maka langkah pemerintah itu bagaimana menegakkan hukum dan mengembangkan undang-undang sesuai dengan perkembangan masyarakat, karena kata "perkembangan hukum yang dibangun" oleh Radhie di atas adalah jelas mengenai hukum yang dicita-citakan berlakunya di masa yang akan datang yang biasa disebut sebagai ius constituendum.

Dalam pandangan Hikmahanto, politik hukum dapat dibedakan menjadi dua dimensi yaitu:8 Pertama, politik hukum yang menjadi alasan dasar diadakannya peraturan perundang-undangan. Dimensi yang pertama disebut dengan "kebijakan dasar" atau basic policy. Kedua, tujuan atau alasan yang muncul dibalik pemberlakuan

7 Teuku Muhammad Radhie, “Pembaruan dan Politik Hukum Dalam Rangka Pembangunan Nasional" M ajalah P risma, N o. 6 tahun Kell Desember 1973, hlm. 4 8 Hikmahanto J, "P olitik H ukum U ndang-undang Bidang ekonomi di Indonesia" . H and O ut kuliah Kebijakan Pembangunan Hukum Program Doktor (S3) Universitas Islam Indonesia. 
Nadi $r$

peraturan perundang-undangan. Dimensi yang kedua ini disebut dengan kebijakan pemberlakuan atau enactment policy.

Adanya Undang-undang Nomor 23 Tahun 2004 tentang Penghapusan Kekerasan Dalam Rumah Tangga (PKDRT) berpotensi disambut dengan beragam respon, baik pro maupun kontra. Namun, kepedulian terhadap tindak kekerasan dalam rumah tangga tidak boleh berhenti dan tetap terus digalang. Pokok-pokok pikiran yang menjadi dasar Undang-Undang Nomor 23 Tahun 2004 yang terkandung di dalam undang-undang tersebut sebagai berikut: Pertama, kasus kekerasan dalam rumah tangga makin menunjukkan peningkatan yang signifikan dari hari ke hari, baik kekerasan dalam bentuk kekerasan fisik atau psikologis maupun kekerasan seksual dan kekerasan ekonomi. Bahkan, sudah menjurus dalam bentuk tindak pidana penganiayaan dan ancaman kepada korban yang dapat menimbulkan rasa ketakutan atau penderitaan psikis berat bahkan kegilaan pada seseorang. Kedua, pandangan yang berpendapat semua kejahatan harus diatur dalam suatu kodifikasi hukum, seperti Kitab Undang-Undang Hukum Acara Pidana atau Kitab Undang-Undang Hukum Pidana adalah pandangan yang tidak mendukung adanya pembaruan hukum sesuai dengan tuntutan perkembangan yang ada, karena peraturan perundang-undangan tersebut belum menyentuh permasalahan yang mendasar. Ketiga, para korban kekerasan dalam rumah tangga mengalami berbagai hambatan untuk dapat mengakses hukum seperti sulit untuk melaporkan kasusnya ataupun tidak mendapat tanggapan positif dari aparat penegak hukum. Ketentuan Hukum Acara Pidana atau perundang-undangan lainnya sejauh ini terbukti tidak mampu memberikan perlindungan bagi korban kekerasan dalam rumah tangga.

Menurut penulis, semua orang, baik pihak penegak hukum, Lembaga Swadaya Masyarakat yang concern terhadap perempuan dan pihak-pihak lain sepakat bahwa kekerasan dalam rumah tangga merupakan bentuk kejahatan. Oleh karena itu, hal itu tidak bisa dibiarkan harus ada regulasi dari pemerintah yang akhirnya melahirkan hukum penghapusan kekerasan dalam rumah tangga.

Usaha penanggulangan kejahatan dengan hukum pidana pada hakekatnya juga merupakan bagian dari usaha penegakan hukum (khususnya penegakan hukum pidana). Oleh karena itu, sering pula dikatakan bahwa politik atau kebijakan hukum pidana merupakan 
bagian pula dari kebijakan penegakan hukum (law enforcement policy). $\mathrm{Hal}$ ini tentunya dilaksanakan melalui sistem hukum peradilan pidana (criminal justice system), yang terdiri dari subsistem Kepolisian, sub sistem Kejaksaan, sub sistem Pengadilan dan sub sistem lembaga pemasyarakatan. ${ }^{9}$

Sudarto mengatakan dalam bukunya "Hukum dan Hukum Pidana", sebagaimana yang dikutip oleh Arief Amrullah dalam bukunya "Politik Hukum Pidana", bahwa menjalankan politik hukum pidana, juga mengadakan pemilihan untuk mencapai hasil perundang-undangan pidana yang paling baik, dalam arti memenuhi syarat keadilan dan dayaguna. Untuk mencapai hasil yang berhasil guna dan berdayaguna, maka para pembuat kebijakan dapat memanfaatkan informasi yang telah disediakan oleh kriminologi. Oleh karena itu, apabila mengabaikan informasi hasil penelitian dari kriminologi akan mengakibatkan terbentuknya perundangundangan yang tidak fungsional. 10

Pandangan Sudarto di atas, sesuai dengan tulisan Marc Ancel sebagaimana yang dikutip oleh Arief Amrullah bahwa in modern science has primary three essensial compenens: criminology, criminal law dan penal policy. Kriminologi mempelajari kejahatan dalam semua aspek. Selanjutnya criminal law menjelaskan dam menerapkan peraturan-peraturan positif atas reaksi masyarakat terhadap fenomena kegiatan. Kemudian penal policy baik sebagai ilmu maupun seni mempunyai tujuan praktis utamanya memungkinkan peraturanperaturan positif dirumuskan lebih baik dan petunjuk tidak hanya kepada legislator yang harus merancang perundang-undangan hukum pidana, tetapi juga pengadilan di mana peraturan-peraturan itu ditetapkan dan penyelenggaraan pemasyarakatan (prison administration) yang memberi pengaruh praktis terhadap putusan pengadilan.

Di samping itu, usaha penanggulangan kejahatan lewat pembaruan undang-undang hukum pidana pada hakikatnya juga merupakan bagian integral dari usaha perlindungan masyarakat social welfare. Oleh karena itu, wajar pulalah apabila kebijakan atau politik

9 Barda Nawawi A rief, Politik H ukum P idana (Jakarta: Pasca Sarjana UI, 1992), hlm. 3 ${ }_{10}$ A ri ef Amrullah, Politik H ukum P idana: D alam Rangka Perlindungan Korban Kejahatan E kon omi di Bidang Perbankan (Malang: Bayumedia Publishing, 2003), hlm.17 
Nadi $r$

hukum pidana juga merupakan bagian integral dari kebijakan atau politik hukum (social policy). Kebijakan sosial dapat pula diartikan sebagai segala usaha yang rasional mencapai kesejahteraan masyarakat dan sekaligus melindungi masyarakat. Jadi, di dalam pengertian social policy sekaligus tercakup di dalamnya social welfare policy dan social defence policy 11

Penal policy atau politik hukum pidana itu, pada dasarnya adalah bagaimana hukum pidana dirumuskan dengan baik dan memberikan pedoman kepada pembuat undang-undang (kebijakan legislatif), kebijakan aplikasi (kebijakan yudikatif). Kebijakan legislatif merupakan tahap yang sangat menentukan bagi tahap-tahap berikutnya karena pada saat perundang-undangan pidana hendak dibuat, maka sudah ditentukan arah yang hendak dituju dengan dibuatnya undang-undang dimaksud dalam konteks ini adalah pembentukan undang-undang tentang penghapusan kekerasan dalam rumah tangga.

Kebijakan untuk membuat peraturan hukum pidana yang baik pada hakekatnya tidak dapat dilepaskan dari tujuan penanggulangan kejahatan. Jadi, kebijakan atau politik hukum pidana (penal policy) juga merupakan bagian dari politik kriminal, maka politik hukum pidana identik dengan pengertian "kebijakan penanggulangan kejahatan dengan hukum pidana". Hukum pidana di Indonesia sebagai sarana untuk menanggulangi kejahatan tampaknya tidak menjadi persoalan. Hal ini terlihat dari praktik perundang-undangan selama ini yang menujukkan bahwa penggunaan hukum pidana merupakan bagian dari kebijakan atau politik hukum yang dianut di Indonesia. Penggunaan hukum pidana dianggap sebagai hal yang wajar dan normal seolah-olah eksistensinya tidak lagi dipersoalkan.12

Dengan demikian, dapatlah ditegaskan bahwa pembaruan hukum pidana (penal refom), termasuk lahirnya Undang-Undang Nomor 23 Tahun 2004, merupakan bagian dari kebijakan/ politik hukum pidana (penal policy). Makna dan hakikat pembaruan hukum pidana berkaitan erat dengan latar belakang dan urgensi diadakannya pembaruan hukum pidana itu sendiri. Latar belakang dan urgensi

11 Barda Nawawi Arief, Bunga Rampai Kebijakan Hukum Pidana (Bandung: Citra Aditya Bakti, 1996), hlm. 30

12 M. Hamdan, Politik H ukum Pidana (Jakarta: RajaGrafindo, 1997), hlm. 21 
diadakannya pembaruan hukum pidana dapat ditinjau dari aspek sosio politik, sosio filosofis, dan sosio kultural atau dari berbagai aspek kebijakan (khususnya kebijakan sosial, kebijakan kriminal dan penegakan hukum). Ini berarti makna dan hakikat pembaruan hukum pidana juga berkaitan erat dengan berbagai aspek itu. Artinya pembaruan hukum pidana juga pada hakikatnya harus merupakan perwujudan dari perubahan dan pembaruan terhadap berbagai aspek dan kebijakan yang melatarbelakangi itu. Dengan demikian, pembaruan hukum pidana pada hakikatnya mengandung makna suatu upaya untuk melakukan "reorientasi dan reformasi" hukum pidana yang sesuai dengan nilai-nilai sentral sosio politik, sosio filosofis dan sosio kultural masyarakat Indonesia yang melandasi kebijakan sosial, kebijakan kriminal dan kebijakan penegakan hukum di Indonesia. Secara singkat dapatlah dikatakan, bahwa pembaruan hukum pidana hakekatnya harus ditempuh dengan pendekatan yang berorientasi pada kebijakan (policy oriented approach) dan sekaligus pendekatan yang berorientasi pada nilai (value orinted approach).13

Berdasarkan uraian di atas, dapatlah disimpulkan bahwa makna dan hakikat pembaruan hukum pidana sebagai berikut: Pertama, dilihat dari sudut pendekatan-pendekatan: (1) Sebagai bagian dari kebijakan sosial. Pembaruan hukum pidana pada hakekatnya merupakan bagian dari upaya untuk mengatasi masalahmasalah sosial (termasuk masalah kemanusiaan) dalam rangka menciptakan atau menunjang tujuan nasional (kesejahteraan rakyat dan sebagainya); (2) sebagai bagian dari kebijakan kriminal. Pembaruan hukum pidana pada hakekatnya merupakan bagian dari upaya perlindungan masyarakat (khususnya upaya penanggulangan kejahatan); (3) sebagai bagian dari kebijakan penegakan hukum. Pembaruan hukum pidana pada hakekatnya merupakan bagian dari upaya memperbarui substansi hukum (legal substance) dalam rangka lebih mengefektifkan penegakan hukum.

Kedua, dilihat dari sudut pendekatan nilai, maka pembaruan hukum pidana pada hakekatnya merupakan upaya melakukan peninjauan dan penilaian kembali (re-orientasi dan reevaluasi) nilanilai sosio politik, sosio filosofis, dan sosio kultural yang melandasi dan memberi isi terhadap muatan normatif dan substansi hukum

13 Arief, Bunga R ampai, hIm. 30 - 32 
Nadi $r$

pidana yang dicita-citakan Bukanlah pembaruan (reformasi) hukum pidana, apabila orientasi nilai-nilai dari hukum pidana yang dicitacitakan misalnya KUHP baru sama saja dengan orientasi nilai-nilai dari hukum pidana lama warisan penjajahan belanda (KUHP lama atau WvS).

Usaha kebijakan hukum pidana dalam mengatur masalah kekerasan dalam rumah tangga merupakan salah satu bagian tugas pemerintah dan DPR untuk memberikan sebuah payung hukum yang sangat memadai bagi saksi sekaligus korban kekerasan dalam rumah tangga, karena politik hukum yang hendak dicapai oleh pemerintah dalam mengundangkan Undang-Undang Nomor 23 Tahun 2004 sebagaimana termuat di dalam Pasal 3 berbunyi bahwa penghapusan kekerasan dalam rumah tangga dilaksanakan berdasarkan asas penghormatan hak asasi manusia; keadilan dan kesetaraan gender;14 nondiskriminasi15; dan perlindungan korban.

Pengertian diskriminasi dalam Pasal 1 dapat disimak dalam Pasal 4, bahwa yang tidak dianggap diskriminasi ialah tindakan yang disebut affirmative action yaitu tindakan khusus yang bersifat sementara dengan tujuan untuk mendapatkan persamaan kesempatan dan perlakuan sama yang nyata antara perempuan dan laki-laki.

Makna pembaruan hukum pidana (penal reform) sebagaimana dikemukakan Arief di atas dalam konteks tulisan ini, merupakan bentuk pembaruan dari hukum pidana yang bersifat umum (KUHP) yang memuat tindak pidana umum ke hukum pidana yang bersifat khusus dalam hal ini Undang-undang Nomor 23 Tahun 2004 sebagai hukum khusus (lex specialis derogat lex generalis).

\section{Karakter Undang-Undang N omor 23 Tahun 2004}

\footnotetext{
14 Kesetaraan gender adalah suatu keadaan di mana perempuan dan laki-laki menikmati status yang setara dan memiliki kondisi yang sama untuk mewujudkan secara penuh hak-hak asasi dan potensinya bagi keutuhan dan kelangsungan rumah tangga secara proporsional

15 Pengertian yang tidak dianggap diskriminasi ialah tindakan yang disebut affirmative action yaitu tindakan khusus yang bersifat sementara dengan tujuan untuk mendapatkan persamaan kesempatan dan perlakuan sama yang nyata antara perempuan dan laki-laki.
} 
Undang-Undang Nomor 23 Tahun 2004 tentang Penghapusan Kekerasan Dalam Rumah Tangga yang diundangkan di Jakarta pada 22 September 2004 merupakan produk hukum era transisional. Hadirnya Undang-Undang Nomor 23 Tahun 2004 dapat dikatakan sebagai produk hukum responsif yang lahir dari lembaga atau institusi responsif politik di tengah beralihnya hak legislasi ke pangkuan pihak legislatif pasca amandemen UUD 1945.

Hukum responsif dapat diartikan sebagai melayani kebutuhan dan kepentingan sosial yang dialami dan ditemukan, tidak oleh pejabat melainkan oleh rakyat. Sifat responsif mengandung arti suatu komitmen kepada subyek hukum atau sesuatu yang dikenai aturan hukum itu dalam tulisan ini adalah Undang-Undang Nomor 23 Tahun 2004 di mana dalam konteks hukum responsif, hukum telah merespon semua kebutuhan masyarakat melalui lembaga yang berwenang dalam konteks Indonesia adalah DPR sebagai institusi pemangku kekuasaan legislasi.

Suatu institusi yang responsif mempertahankan secara kuat hal-hal yang essensial bagi integritasnya sembari tetap memperhatikan atau memperhitungkan keberadaan kekuatankekuatan baru di dalam lingkungannya. Untuk melakukan itu, hukum responsif melakukan cara-cara di mana keterbukaan dan integritas dapat saling menopang walaupun terdapat benturan diantara keduanya. Lembaga responsif ini menganggap tekanantekanan sosial sebagai sumber pengetahuan dan kesempatan untuk mengoreksi diri.16 Konsep hukum responsif melihat suatu pemecahan untuk dilema ini yang mencoba untuk mengkombinasikan keterbukaan dengan integritas. Jawaban dari hukum responsif adalah adaptasi selektif ke dalam tuntutan-tuntutan dan tekanan-tekanan baru.

Karakter produk hukum responsif adalah kekuasaan yang didasarkan atas hukum yang dicita-citakan, tetapi sekarang tidak lagi diartikan sebagai kepantasan prosedural formal, melainkan sebagai reduksi secara progresif dari kesewenang-wenangan dan penyalahgunaan kekuasaan dalam kehidupan politik, sosial dan ekonomi. Jadi hukum responsif tidak membuang ide tentang

16 Philippe Nonet dan Philip Selznick, H ukum Responsif, Pilihan di M asa Transisi, terj. (Jakarta: Elsam dan Huma, 2003), hlm. 62. 
Nadi $r$

keadilan, melainkan ia memeperluasnya untuk mencakup keadilan substantif.

Secara garis besar karakter produk hukum responsif adalah sebagai berikut:17 (1) Pergeseran penekanan dari aturan-aturan ke prinsip-prinsip dan kedaulatan tujuan; (2) pentingnya kewajiban dan kesopanan masyarakat dalam menyambut aturan hukum baik sebagai salah satu tujuan hukum maupun sebagai tujuan akhir yang ingin dicapai oleh produk hukum responsif; dan (3) partisipasi hukum dan partisipasi politik, di saat sistem hukum memperluas sumber-sumber kritisnya, sistem hukum itu mendelegasikan lebih banyak diskresi untuk memutuskan hal-hal yang otoritatis. Partisipasi hukum diperluas hingga menjangkau pembuatan dan interpretasi kebijakan hukum.

Hadirnya Undang-Undang Nomor 23 Tahun 2004 telah merespon semua kekerasan dalam rumah tangga yang sebelumnya tidak diatur secara khusus. Oleh karena itu, dalam konteks sistem hukum Indonesia Undang-Undang Nomor 23 Tahun 2004 mampu memenuhi keadilan substantif dalam lingkup rumah tangga.

Dalam kaitannya dengan hukum progresif sebagaimana pandangan Satjipto Rahardjo, bahwa hukum progresif lahir untuk menegaskan bahwa hukum adalah untuk manusia, dan bukan sebaliknya. ${ }^{18}$ Lebih lanjut ia mengemukakan hukum itu bukan hanya bangunan peraturan, melainkan juga bangunan ide, kultur, dan citacita. Karena tujuan hukum adalah membahagiakan manusia"letak persoalan hukum adalah di manusianya. ${ }^{19}$

\section{Penutup}

Berdasarkan uraian di atas, dapat disimpulkan bahwa politik hukum pidana dalam upaya penghapusan kekerasan dalam rumah tangga merupakan tindakan pemerintah dalam bentuk norma hukum dengan mengundangkan Undang-Undang N omor 23 Tahun 24, yang menggolongkan kekerasan dalam rumah tangga merupakan tindak pidana. Oleh karena itu, segala bentuk kekerasan seperti kekerasan fisik, psikis, seksual, penelantaran rumah tangga (kekerasan

\footnotetext{
$17 \mathrm{lbid}, \mathrm{hlm} .62-77$

18 Satjipto Rahardjo, “Hukum Progresif: Hukum yang Membebaskan”, Jurnal H ukum P rogresif, Vol. 1 Nomor 1/ A pril 2005.

19 Satjipto Rahardjo, M embedah H ukum Progresif, (Jakarta: Kompas, 2006), hlm. 3-9
} 
ekonomi), dilarang dengan keras Undang-Undang Nomor 23 Tahun 2004 tentang Penghapusan Kekerasan Dalam Rumah Tangga, dengan ancaman pidana yang berat.

Adapun politik hukum pidana (penal policy) yang diwujudkan di dalam Undang-undang Nomor 23 ahun 2004 dalam rangka penghapusan kekerasan dalam rumah tangga dilaksanakan berdasarkan asas penghormatan hak asasi manusia, keadilan dan kesetaraan gender, nondiskriminasi, dan perlindungan korban.

\section{D aftar Pustaka}

Amrullah, Arief. Politik Hukum Pidana: Dalam Rangka Perlindungan Korban Kejahatan Ekonomi di Bidang Perbankan. Malang: Bayumedia Publishing, 2003.

Arief, Barda Nawawi. Politik Hukum Pidana. Jakarta: Bahan Bacaan Pasca Sarjana Universitas Indonesia, 1992.

Bunga Rampai Kebijakan Hukum Pidana. Bandung: Citra Aditya Bakti, 1996.

M embedah H ukum Progresif. Jakarta: Kompas, 2006.

Ciciek, Farha. Ikhtiar M engatasi Kekerasan dalam Rumah Tangga Jakarta: The Asian Fondatian, 1999.

Hamdan, M. Politik H ukum Pidana. Jakarta: Raja Grafindo Persada, 1997.

Herkutanto. Kekerasan Terhadap Perempuan dan Sistem Hukum Pidana: Pendekatan dari Sudut Kedokteran. Bandung: Alumni, 2000.

J, Hikmahanto. "Politik Hukum Undang-Undang Bidang Ekonomi di Indonesia". Hand Out kuliah Kebijakan Pembangunan Hukum Program Doktor (S3) Universitas Islam Indonesia.

Nonet, Philippe dan Selznick, Philip. Hukum Responsif, Pilihan di M asa Transisi, terj. Rafael Edy Bosco. Jakarta: Elsam dan Huma, 2003. 
Nadir

Radhie, Teuku Muhammad. "Pembaruan dan Politik Hukum dalam Rangka Pembangunan Nasional" dalam Majalah Prisma, No. 6 tahun Kell Desember 1973.

Rahardjo, Satjipto. “Hukum Progresif: Hukum yang Membebaskan”, Jurnal H ukum Progresif, Vol. 1 Nomor 1/ A pril 2005.

Suparno, Indriyati, et. al. Persepsi Pengetahuan Perempuan dan Gambaran Situasi Kekerasan terhadap Istri. Solo: Solidarity Kemanusiaan Perempuan, 2002.

Syukrie, Erna Sofyan. "Pemberdayaan Perempuan Dalam Pembangunan Berkelanjutan", makalah disampaikan dalam Seminar dan Loka Karya Pembangunan Hukum Nasional ke VIII diselenggarakan oleh Badan Pembinaan Hukum Nasional Departemen Hukum dan Kehakiman RI Tanggal 14 sampai dengan 18 Juli 2003 di Hotel Kartika Plaza, Denpasar, Bali, 2003. 